\title{
MIDAZOLAM MALEATE INDUCTION IN PATIENTS WITH ISCHAEMIC HEART DISEASE: HAEMODYNAMIC OBSERVATIONS
}

\author{
J.G. Reves, Paul N. Samuelson and Sandra Lewis
}

Midazolam, maleate is a water soluble benzodiazepine used for the intravenous induction of general anaesthesia ${ }^{1-4}$ and for premedication. ${ }^{3}$ The aqueous solubility of midazolam maleate probably accounts for the pharmacological differences between it and diazepam. Water solubility permits formulation in a less irritating vehicle than diazepam, ${ }^{\prime}$ and the duration of action of midazolam maleate is relatively brief at approximately four minutes. ${ }^{5.6}$ It compares favourably with thiopentone for induction ${ }^{2,7}$ and maintenance ${ }^{2}$ of anaesthesia.

There are no reports on the cardiovascular effects of midazolam maleate in man. Laboratory results, although conflicting in some regards, ${ }^{8.9}$ suggest that midazolam maleate has minimal effects on the canine cardiovascular system over a wide dose range. Since our data on dogs demonstrated small haemodynamic changes that included preservation of perfusion pressure and reduction of several correlates of myocardial oxygen consumption 8 we thought it important to investigate the cardiovascular effects of midazolam maleate in patients with ischaemic heart disease. This has been done in the present study in patients about to undergo myocardial revascularization opetations.

\section{METHODS}

Ten patients electively scheduled for myocardial revascularization operations were invited to participate and gave informed consent to enter the investigation. The study was approved by the Institutional Review Board for Human Investigation. All patients were premedicated with intramuscular morphine sulfate $0.1 \mathrm{mg} \cdot \mathrm{kg}^{-1}$ and scopolamine $6-8 \mu \mathrm{g} \cdot \mathrm{kg}^{-1}, 60$ to 90 minutes before induction. In a preinduction area catheters were placed into two peripheral veins. the radial artery, and a Swan-Ganz triple lumen thermodilution catheter was floated into the pul-

J.G. Reves, M.D. Professor, Paul N. Samuelson, M.D. Associate Professor. Sandra Lewis, M.D. Resident. Cardiovascular Section. Department of Anaesthesiology. School of Medicine, University of Alabama, Birmingham. Alabama 35294, U.S.A.
TABLE I

Patient Characteristics

\begin{tabular}{l}
\hline Number: 10 males \\
Age: 57 years (47-61) \\
Weight: $78 \mathrm{~kg}(56-93)$ \\
BSA: $\quad 1.95 \mathrm{~m}^{2}(1.64-2.33)$ \\
Coronary arteries > 70 per cent occluded: \\
left 10, right 9 , circumflex 5 \\
Past history: \\
Myocardial infarction $\quad 7$ \\
Hypertension \\
LVEDP $\geq 12$ at cath $\quad 5$ \\
Medications: \\
Propranolol 40-160 $\mathrm{mg}$ q d \\
Nitrates \\
Digoxin \\
Antiarrhythmic \\
Number grafts performed 2.6 (1-5) (one \\
patient also had resection of left ventric- \\
ular and aortic aneurysm and aortic valve \\
replacement) \\
\hline
\end{tabular}

monary artery. Electrocardiogram leads were placed to monitor Lead II and VS. Measured parameters included heart rate and rhythm, systemic systolic/diastolic blood pressure, mean systemic blood pressure, pulmonary artery pressure, pulmonary artery occluded pressure, mean right atrial pressure, cardiac output (duplicate thermodilution) and arterial and mixed venous blood gas tensions. All measurements were made at end-expiration. Derived data were cardiac index, stroke index, heart rate-systolic blood pressure product, systemic vascular resistance index, pulmonary vascular resistance index, left ventricular stroke work index and right ventricular stroke work index. Formulae for these calculations have been previously reported. ${ }^{10}$

The experimental protocol involved measurements at four time-periods: (1) baseline, breathing room air in the preinduction area; (2) baseline, breathing 100 per cent oxygen (operating room); (3) one to two minutes after induction with intravenous midazolam maleate $\left(0.2 \mathrm{mg} \cdot \mathrm{kg}^{-1}\right)$; (4) four to five minutes after midazolam maleate injected over five to ten seconds into a freely running intravenous infusion. During induction,

Canad, Anaesth. Soc. J., vol. 26, no. 5, September 1979 
all patients breathed 100 per cent oxygen and respiration was assisted if respiratory depression or apnoen occurred.

The raw data were analyzed using multifactorial analysis of variance and the New Duncan's Multiple Range test. Differences with $p<0.05$ were considered significant.

\section{Results}

The study group consisted of ten men of mean age 57 years, mean weight $78 \mathrm{~kg}$ and mean body surface area $1.95 \mathrm{~m}^{2}$. In each, induction was with midazolam maleate $0.2 \mathrm{mg} \cdot \mathrm{kg}^{-1}$, and the induction time ranged from 30 to 90 seconds (mean 44 seconds). Apnoea occurred in six of the eight patients in whom it was recorded and ranged from 15-60 seconds. In two patients the presence or absence of apnoea was not recorded. The $\mathrm{PaCO}_{2}$ increased significantly from a mean of $5.32 \pm 0.11$ $\mathrm{kPa}(40 \pm 1.3 \mathrm{~mm} \mathrm{Hg})$ at two minutes and $6.1 \pm$ $0.17 \mathrm{kPa}(46 \pm 1.3 \mathrm{~mm} \mathrm{Hg})$ at five minutes after administration of midazolam maleate. The $\mathrm{pH}$ decreased from $7.36 \pm 0.012$ to $7.32 \pm 0.01$ at two minutes and $7.3 \pm 0.009$ at five minutes; but there were no significant changes in $\mathrm{Pa}_{\mathrm{O}_{2}}$ from $41.6 \pm$ $1.82 \mathrm{kPa}(313 \pm 13.7 \mathrm{~mm} \mathrm{Hg})$. There was no pain on injection of midazolam maleate.

The measured haemodynamic values at the four time periods during the study are recorded in Table II and the derived data in Table III. Transfer of the patients from the preinduction area. where the monitoring devices were placed, to the operating room and administration of 100 per cent oxygen resulted in sustained (over five minutes) significant $(p<0.01)$ increases in systemic, pulmonary and pulmonary artery occluded pressures. There were significant increases in the heart rate-systolic pressure product from mean of 6812 to $8338(\mathrm{p}<0.05$ ) and systemic vascular resistance index from mean of 690 to 923 ( $p<$ $0.01)$. Midazolam maleate significantly $(p<0.01)$ lowered systemic systolic, diastolic and mean blood pressure. The heart rate increased from a mean of 55 to 66 beats per minute $(p<0.01)$. Stroke volume, left and right ventricular stroke work index and systemic vascular resistance index were all significantly $(p<0.01)$ reduced by midazolam maleate. Heart rate-systolic pressure product, cardiac index, stroke index, pulmonary vascular resistance inde $x$, mean right artial pressure, mean pulmonary artery occluded pressure and mean pulmonary artery pressure all remained unchanged after midazolam maleate. There were no differences in the haemodynamic values be-
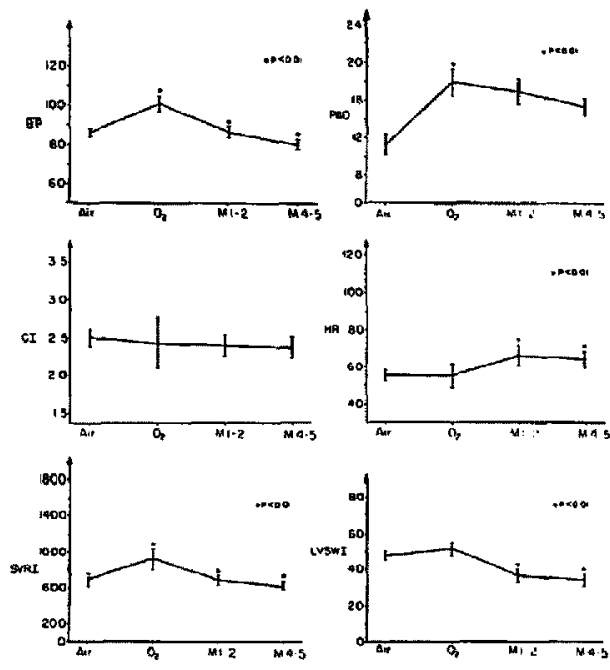

Figure I A composite illustration of the mean systolic blood pressure $(\overline{\mathrm{BP}})$, pulmonary artery occluded pressure ( $\overline{\mathrm{PAO}})$, cardiac inde $\mathrm{X}(\mathrm{CI})$, heart rate (HR). systemic vascular resistance index (SVRI) and left ventricular stroke work index (LVSWI) values determined while breathing room air in the pre-induction area (Air), breathing 100 per cent oxygen in the operating room $\left(\mathrm{O}_{2}\right)$. one to two minutes after $0.2 \mathrm{mg} \cdot \mathrm{kg}^{-1}$ midazolam maleate ( $\mathrm{M} \mid-2)$, and four to five minutes after midazolam maleate (M 4-5). The statistical comparison is $A$ ir against oxygen, $M I-2$ and $M$ 4-5. For the statistical comparison of all points against each other. see Tables II and III.

tween the two-minute and the five-minute sample periods after administration of midazolam maleate except for a continued decrease in systemic blood pressure toward the room air baseline. A composite illustration of the mean changes in mean systemic blood pressure, heart rate, cardiac index and pulmonary artery occluded pressure is shown in Figure 1. Throughout the study period, there were no electrocardiographic changes suggestive of myocardial ischaemia.

The effect of midazolam maleate on individual patients with elevated pulmonary artery occluded pressure is shown in Table IV. The pulmonary artery occluded pressure decreased in all patients and fell from a mean $2.82 \mathrm{kPa}(21.2$ $\mathrm{mm} \mathrm{Hg}$ ) to $2.13 \mathrm{kPa}(16.0 \mathrm{~mm} \mathrm{Hg})$ five minutes after midazolam maleate. There was a consistent increase in cardiac index and heart rate, while left ventricular stroke work index. mean systemic blood pressure and systemic vascular resistance index dropped 1077 to 653 dynes. sec $\cdot \mathrm{cm}^{-s} / \mathrm{m}^{2}$. The 40 per cent decrease in sys 
TABLE II

Mean ( \pm S.E.) Measured Variable Before and After Midazolam Maleate $\left(0.2 \mathrm{mg} \cdot \mathrm{kg}^{-1}\right)$

\begin{tabular}{lcrrrr}
\hline & Units & \multicolumn{1}{c}{ Air } & \multicolumn{1}{c}{$\mathrm{O}_{2}$} & \multicolumn{1}{c}{ M 1-2 } & M 4-5 \\
\hline HR & Beats/min & $55 \pm 3.0$ & $55 \pm 6.6$ & $66 \pm 5.3$ & $64 \pm 4.6$ \\
SBP & $\mathrm{mm} \mathrm{Hg}$ & $125 \pm 5.1$ & $154 \pm 5.1$ & $131 \pm 4.5$ & $120 \pm 4.4$ \\
DBP & $\mathrm{mm} \mathrm{Hg}$ & $61 \pm 2.3$ & $74 \pm 2.1$ & $68 \pm 2.4$ & $61 \pm 2.3$ \\
$\overline{\text { BP }}$ & $\mathrm{mm} \mathrm{Hg}$ & $86 \pm 1.6$ & $102 \pm 3.8$ & $87 \pm 2.9$ & $81 \pm 2.6$ \\
$\overline{\text { RAP }}$ & $\mathrm{mm} \mathrm{Hg}$ & $9 \pm 0.9$ & $12 \pm 0.7$ & $13 \pm 1.5$ & $13 \pm 1.1$ \\
$\overline{\text { PAP }}$ & $\mathrm{mm} \mathrm{Hg}$ & $19 \pm 1.7$ & $27 \pm 2.2$ & $26 \pm 2.0$ & $24 \pm 1.4$ \\
$\overline{\text { PAO }}$ & $\mathrm{mm} \mathrm{Hg}$ & $11.2 \pm 1.03$ & $17.9 \pm 1.35$ & $16.9 \pm 1.44$ & $15.3 \pm 0.91$ \\
CO & L/min & $4.8 \pm 0.22$ & $4.8 \pm 0.74$ & $4.6 \pm 0.24$ & $4.4 \pm 0.29$
\end{tabular}

Comparison of Significance Between Observed Vartables

\begin{tabular}{lllllllll}
\hline & HR & SBP & DBP & $\overline{\text { BP }}$ & $\overline{\text { RAP }}$ & $\overline{\text { PAP }}$ & $\overline{\text { PAO }}$ & CO \\
\hline Air vs $\mathrm{O}_{2}$ & N.S. & 0.01 & 0.01 & 0.01 & 0.01 & 0.01 & 0.01 & N.S. \\
Air vs $\mathrm{M}_{1-2}$ & 0.01 & N.S. & 0.05 & N.S. & 0.01 & 0.01 & 0.01 & N.S. \\
Air vs $\mathrm{M}_{4-5}$ & 0.01 & N.S. & N.S. & N.S. & 0.01 & 0.01 & 0.01 & N.S. \\
$\mathrm{O}_{2}$ vs $\mathrm{M}_{1-2}$ & 0.01 & 0.01 & 0.05 & 0.01 & N.S. & N.S. & N.S. & N.S. \\
$\mathrm{O}_{2}$ vs $\mathrm{M}_{4-5}$ & $\mathbf{0 . 0 1}$ & 0.01 & 0.01 & 0.01 & N.S. & N.S. & N.S. & N.S. \\
$\mathrm{M}_{1-2}$ vs $\mathrm{M}_{4-5}$ & N.S. & 0.05 & $\mathbf{0 . 0 1}$ & N.S. & N.S. & N.S. & N.S. & N.S. \\
\hline
\end{tabular}

Where: $\mathrm{HR}=$ heart rate, $\mathrm{SBP}=$ systolic blood pressure, $\mathrm{DBP}=$ diastolic blood pressure, $\overline{\mathrm{BP}}=$ mean systemic blood pressure, $\overline{\mathrm{RAP}}=$ mean right atrial pressure, $\overline{\mathrm{PAP}}=$ mean pulmonary artery pressure, $\overline{\mathrm{PAO}}=$ mean pulmonary artery accluded pressure, $\mathrm{CO}=$ cardiac output, Air = Pre-induction area control breathing room air, $\mathrm{O}_{2}=$ operating room control breathing $100 \%$ oxygen, $\mathrm{M}_{1-2}=$ one to two minutes after midazolam maleate administration, and $M_{4-5}=$ four to five minutes after midazolam maleate administration.

TABLE III

Mean ( \pm S.E.) Derived Variagles Before and Aftem Midazolam Maleate $\left(0.2 \mathrm{mg}^{-\mathrm{kg}^{-1}}\right.$ )

\begin{tabular}{llcccc}
\hline & Units & Air & $O_{2}$ & M 1-2 & M 4-5 \\
\hline CI & $\mathrm{L} / \mathrm{min} / \mathrm{m}^{2}$ & $2.5 \pm 0.10$ & $2.4 \pm 0.34$ & $2.4 \pm 0.14$ & $2.4 \pm 0.14$ \\
SI & $\mathrm{m} / \mathrm{min} / \mathrm{m}^{2}$ & $46 \pm 1.9$ & $44 \pm 1.9$ & $38 \pm 2.8$ & $38 \pm 2.8$ \\
SV & $\mathrm{ml} / \mathrm{min}$ & $89 \pm 3.9$ & $86 \pm 5.1$ & $73 \pm 5.1$ & $72 \pm 5.0$ \\
LVSWI & $\mathrm{g} \cdot \mathrm{m} / \mathrm{m}^{2}$ & $46.9 \pm 2.55$ & $50.8 \pm 4.02$ & $36.2 \pm 3.75$ & $36.5 \pm 2.93$ \\
RSVWI & $\mathrm{g} \cdot \mathrm{m} / \mathrm{m}^{2}$ & $6.5 \pm 1.07$ & $8.8 \pm 1.17$ & $6.3 \pm 0.69$ & $5.2 \pm 0.68$ \\
SVRI & dynes $\cdot \mathrm{sec} \cdot \mathrm{cm}^{-5} / \mathrm{m}^{2}$ & $689 \pm 66.3$ & $923 \pm 123.1$ & $685 \pm 52.6$ & $623 \pm 49.4$ \\
PVRI & dynes $\cdot \mathrm{sec} \cdot \mathrm{cm}^{-5} / \mathrm{m}^{2}$ & $65 \pm 9.2$ & $83 \pm 11.6$ & $80 \pm 9.5$ & $80 \pm 8.66$ \\
RPP & Beats $\mathrm{mm} \mathrm{Hg} / \mathrm{min}^{2}$ & $6812 \pm 339.5$ & $8338 \pm 914.9$ & $8638 \pm 722.9$ & $7628 \pm 514.4$
\end{tabular}

Comparison of Stgnificance Between Derived Variables

\begin{tabular}{lllllllll}
\hline & CI & SI & SV & LVSWI & RVSWI & SVRI & PVRI & RPP \\
\hline Air vs $\mathrm{O}_{2}$ & N.S. & N.S. & N.S. & N.S. & 0.05 & 0.01 & N.S. & N.S. \\
Air vs $M_{1-2}$ & N.S. & 0.01 & 0.01 & 0.01 & N.S. & N.S. & N.S. & 0 05 \\
Air vs M & N.S. & 0.01 & 0.01 & 0.01 & N.S. & N.S. & N.S. & 0.01 \\
$\mathrm{O}_{2}$ vs $\mathrm{M}_{1-2}$ & N.S. & 0.01 & 0.01 & 0.01 & 0.01 & 0.01 & N.S. & N.S. \\
$\mathrm{O}_{2}$ vs $\mathrm{M}_{4-5}$ & N.S. & $\mathbf{0 . 0 1}$ & 0.01 & 0.01 & 0.01 & 0 01 & N.S. & N.S. \\
$\mathrm{M}_{1-2}$ vs $\mathrm{M}_{4-3}$ & N.S. & N.S. & N.S. & N.S. & N.S. & N.S. & N.S. & N.S. \\
\hline
\end{tabular}

Where: $\mathrm{Cl}=$ cardiac index, $\mathrm{SI}=$ stroke index, $\mathrm{SV}=$ stroke volume, $\mathrm{LVSWI}=$ left ventricular stroke work index, RVSWI = right ventricular stroke work index, SVRI = systemic vascular resistance index, PVRI $=$ pulmonary vascular resistance index, RPP = heart rate systolic blood pressure index, Air = Pre-induction area control breathing room air, $\mathrm{O}_{2}=$ operating room control breathing $100 \%$ oxygen, $\mathrm{M}_{1-2}=$ one to two minutes after midazolam maleate administration, and $\mathrm{M}_{4-5}=$ four to five minutes after midazolam maleate administration. 


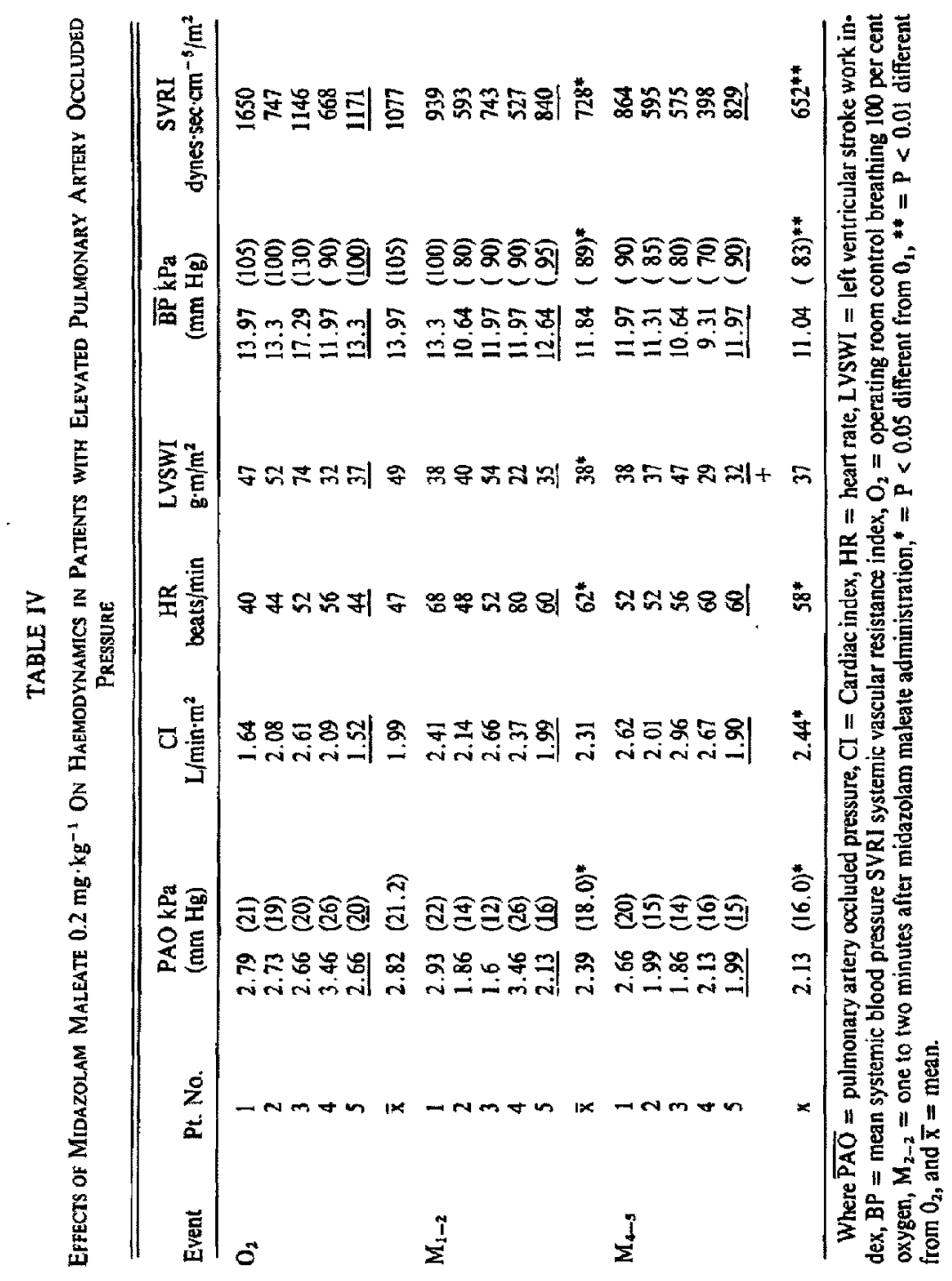


temic vascular resistance index five minutes after midazolam maleate in these patients contrasts to a decrease of only 22 per cent in the sub-group with a pulmonary artery occluded pressure less than $2.26 \mathrm{kPa}$ ( $17 \mathrm{~mm} \mathrm{Hg}$ ).

\section{Discussion}

Our data indicate that intravenous midazolam maleate $0.2 \mathrm{mg} \cdot \mathrm{kg}^{-1}$ has relatively minor effects on the cardiovascular system of man with ischaemic heart disease. Indeed, the most striking haemodynamic changes during the study period were associated with transfer of the patients into the operating room and breathing 100 per cent oxygen before induction. Subsequent administration of a hypnotic dose of midazolam maleate returned most parameters toward the original room air values. Midazolam maleate increased heart rate eleven beats/min and $\mathrm{Pa}_{\mathrm{CO}_{2}}$ rose from 5.32 to $6.12 \mathrm{kPa}$ (40 to 46 torr) ( $p<0.01$ ), while none of the remaining parameters were significantly changed.

These haemodynamic changes are modest and observations on blood pressure, cardiac output, stroke volume, and peripheral resistance parallel those accompanying deep sleep in normal volunteers". The haemodynamic changes seen with midazolam maleate induction are also similar to those reported with diazepam sedation. Diazepam $0.1 \mathrm{mg} \cdot \mathrm{kg}^{-1}$ in patients with ischaemic heart disease reduced the systemic pressure, while cardiac index and peripheral resistance remained unchanged'2. Diazepam sedation significantly decreased left ventricular end-diastolic pressure, an effect which was more pronounced in patients with ischaemic heart disease in whom this pressure was elevated. In our study, the pulmonary artery occluded pressure, which approximates left ventricular end-diastolic pressure, fell only slightly from a mean of 2.38 to 2.25 $\mathrm{kPa}(17.9$ to $16.9 \mathrm{~mm} \mathrm{Hg}$ ) with midazolam maleate; but in the one patient with markedly elevated pulmonary artery occluded pressure of $3.46 \mathrm{kPa}(26 \mathrm{~mm} \mathrm{Hg})$ it decreased $2.13 \mathrm{kPa}(16 \mathrm{~mm}$ $\mathrm{Hg}$ ) aftel midazolam maleate induction, while the cardiac index increased from 1.52 to 1.90 $1 / \mathrm{min} \cdot \mathrm{m}^{2}$. The response of that patient and the others (Table IV) with elevated pulmonary artery occluded pressure greater than $2.26 \mathrm{kPa}(17 \mathrm{~mm}$ $\mathrm{Hg}$ ) suggests that midazolam maleate improves cardiac function.

In terms of haemodynamic effects, induction of anaesthesia with midazolam maleate and diazepam are very similar in patients with ischaemic heart disease. ${ }^{14-16}$ Jackson showed that induction with diazepam $0.4 \mathrm{mg} \cdot \mathrm{kg}^{-1}$ in eight patients with ischaemic heart disease was associated with a 15 per cent $(p<0.05)$ decrease in mean systemic pressure, but no significant change in cardiac index, systemic vascular resistance and left ven. Iricular stroke index." These changes are similar to those of midazolam maleate, except that the heart rate was unchanged with diazepam and increased with midazolam maleate. The disparity in heart rate data accounts for differences in heart rate-systolic pressure product, which is unchanged with midazolam maleate and dectersed with diazepam. The observed increase in heart rate with midazolam maleate is also at variance with changes of sleep. "diazepam sedation'2 and induction of anaesthesia with diazepam in patients with ischaemic heart disease, in whom the heart rate is unchanged or decreased. However. Prakash reported an increase in heart rate in patients with ischaemic heart disease anaesthetized with diazepam $0.6 \mathrm{mg} \cdot \mathrm{kg}^{-1}$ in whom the $\mathrm{Pa}_{\mathrm{CO}_{2}}$ ranged from 4.79 to $5.98 \mathrm{kPa}(36-45 \mathrm{~mm}$ $\mathrm{Hg}$ ). ${ }^{5}$ In our patients, the $\mathrm{PaCO}_{2}$ rose from a mean of 5.32 to $6.11 \mathrm{kPa}(40$ to $46 \mathrm{~mm} \mathrm{Hg})$, despite assisted ventilation. We attempted to maintain normal $\mathrm{Pa}_{\mathrm{CO}_{2}}$, but slight increases resulted and may have affected the haemodynamic results, although the peak mean $\mathrm{Pa}_{\mathrm{CO}_{2}}$ value was $6.11 \mathrm{kPa}$ $(46 \mathrm{~mm} \mathrm{Hg}$ ) five minutes after administration of midazolam maleate and this is not much above the normal physiological range. However, it is possible that the increase in heart rate to 66 beats per minute seen with midazolam maleate reflects the rise in $\mathrm{PaCO}_{2}$. There is a linear relationship between rises in heart rate and $\mathrm{Pa}_{\mathrm{CO}_{2}}$ in conscious and lightly anaesthetized man. "In our patients the largest individual increases in heart rate accompanied the greatest rise in $\mathrm{Pa}_{\mathrm{CO}_{2}}$.

This study was not designed to evaluate the ventilatory response to midazolam maleate, but transient periods of apnoea and depressed respiration were noted immediately after injection of the drug. This effect has also been reported with sedative doses of diazepam. ${ }^{18}$ Respiratory depression commonly complicates induction of anaesthesia with barbiturates, benzodiazepines, and narcotics. Midazolam maleate $0.15 \mathrm{mg} \cdot \mathrm{kg}^{-1}$ causes significantly $(\mathrm{p}<0.001)$ less apnoea than thiopentone $3 \mathrm{mg} \cdot \mathrm{kg}^{-1}$ during induction, and about the same as diazepam. ${ }^{4}$ The exact degree and mechanism of respiratory depression from midazolam maleate remains to be determined in subsequent investigations.

The patients in this study all had symptomatic 
ischaemic heart disease for which they were to have elective myocardial revascularization operations. The goal of anaesthetizing patients with ischaemic heart disease is to minimize changes in the balance between myocardial oxygen supply and consumption. Techniques associated with haemodynamic fluctuations, such as ketamine or morphine, are less desirable ${ }^{19}$ than those designed to minimize these changes. ${ }^{20.21}$ In terms of drug effects on myocardial oxygen supply, it is useful to ask what happens to $\mathrm{Pa}_{\mathrm{O}_{2}}$, cardiac output, and diastolic blood pressure. Midazolam maleate did not change $\mathrm{Pa}_{02}$ or cardiac output, although the diastolic blood pressure dropped slightly $(0.8 \mathrm{kPa}(6 \mathrm{~mm} \mathrm{Hg}))$. It is presumed that myocardial oxygen supply was maintained. Since myocardial oxygen consumption was not measured, indirect estimates must be relied upon. These include heart rate, systolic blood pressure and pulmonary artery occluded pressure as indices of wall tension and left ventricular stroke work index as an indirect index of contractility. The heart rate went up 11 beats per minute from a control of 55 but remained within acceptable normal limits. Other indirect estimates of myocardial oxygen consumption, such as left ventricular stroke work index, systemic systolic blood pressure and pulmonary artery occluded pressure all decreased. Additionally, the heart rate-systolic blood pressure product, perhaps the most reliable simple predictor of myocardial oxygen consumption in patients with ischaemic heart disease, ${ }^{22}$ did not significantly change after midazolam maleate. Thus, midazolam maleate appeared to have little effect on myocardial oxygen supply and consumption and was a safe agent for rapid induction of anaesthesia in patients with ischaemic heart disease. This investigation did not examine the suitability of midazolam maleate to maintain anaesthesia for tracheal intubation and during the surgical procedures. Since midazolam maleate is a relatively short acting drug, other anaesthetics would be required to maintain anaesthesia; but for short anaesthetic procedures such as cardioversion, midazolam maleate should be ideal. Certainly midazolam maleate is comparable to diazepam in terms of maintaining stability of the cardiovascular system and it is a superior alternative to diazepam when a short acting, painless benzodiazepine is needed for induction of anaesthesia.

\section{SUMMARY}

Midazolam maleate is a new water soluble ben- zodiazepine used for induction of anaesthesia. Ten patients with symptomatic ischaemic heart disease were premedicated intramuscularly with morphine $0.1 \mathrm{mg} \cdot \mathrm{kg}^{-1}$ and scopolamine $6-8$ $\mu \mathrm{g} \cdot \mathrm{kg}^{-1}, 60-90$ minutes before induction. The heart rate. systolic/diastolic blood pressure, mean systolic blood pressure, mean pulmonary artery blood pressure, pulmonary artery occluded pressure, mean right atrial pressure, cardiac output (duplicate thermodilution) and arterial blood gas tensions were measured at four time periods: (1) after instrumentation while breathing room air, (2) after transfer to the operating room while breathing 100 per cent oxy. gen by mask, (3) one to two minutes after intravenous midazolam maleate $0.2 \mathrm{mg} \cdot \mathrm{kg}^{-1}$ and (4) four to five minutes after midazolam maleate. The cardiac index, stroke index, heart ratesystolic blood pressure product, systemic vascular resistance index, pulmonary vascular resistance index, left ventricular stroke work index and right ventricular stroke work index were calculated for each of the study time-periods from the measured parameters.

Midazolam maleate anaesthetized all patients and times for induction ranged from 30 to 90 seconds (mean 44). Apnoea occurred in 75 per cent of patients and ventilation was assisted in those instances. The $\mathrm{Pa}_{2}$ was unchanged by midazolam maleate, but the $\mathrm{Pa}_{\mathrm{CO}_{2}}$ rose significantly $(p<0.02)$ from $5.32 \pm 0.19$ to $5.85 \pm$ $0.17 \mathrm{kPa}(40 \pm 1.4$ to $44 \pm 1.3 \mathrm{~mm} \mathrm{Hg})(1-2 \mathrm{~min})$ and $6.1 \pm 0.17 \mathrm{kPa}(46 \pm 1.3 \mathrm{~mm} \mathrm{Hg})(4-5 \mathrm{~min}-$ utes after midazolam maleate).

Haemodynamic effects of midazolam maleate were minor and in most cases less than those associated with transfe $r$ of the patients to the operating room when the systemic systolic/diastolic blood pressure, mean systemic blood pressure, mean right atrial pressure. pulmonary artery occluded pressure and systemic vascular resistance index all significantly increased $(p<$ 0.01 ). Midazolam maleate significantly reduced systemic systolic/diastolic pressure, mean systemic blood pressure, stroke volume. left and right ventricular stroke work index and systemic vascular resistance index toward the original resting control.

The heart rate rose from $55 \pm 6.61066 \pm 5.3$ beats per minute $(p<0.01)$ one to two minutes after midazolam maleate, and the mean right atrial pressure, mean pulmonary artery pressure, pulmonary artery occluded pressure, cardiac index, stroke index, pulmonary vascular resis. tance index and heart rate-systolic blood pres- 
sure product remained unchanged. There were no further significant changes four to five minutes after midazolam maleate, except in systemic systolic/diastolic pressure which continued to decline to the level of the resting control (125/61).

It is concluded that the rapid action of midazolam maleate and its modest effects on haemodynamic parameters, make it a safe and efficacious induction agent in patients with ischaemic heart disease.

\section{RÉSUMÉ}

Le maléate de midazolam est une nouvelle benzodiazépine soluble dans l'eau utilisée comme agent d'induction en anesthésie. Notre étude a porté sur dix patients présentant une pathologie coronarienne symptomatique et soumis à une chirurgie de revascularisation. Une injection de morphine (à la dose de $0.1 \mathrm{mg} \cdot \mathrm{kg}^{-1}$ ) et de scopolamine (6 à $\left.8 \mu \mathrm{g} \cdot \mathrm{kg}^{-1}\right)$ a été administrée en prémédication 60 à 90 minutes avant l'induction. La fréquence cardiaque, les pressions systémiques systolique, diastolique et moyenne, la pression pulmonaire moyenne ct la pression capillaire bloquée. la pression auriculaire droite moyenne, le dëbit cardiaque par thermodilution ainsi que les gaz artériels ont été mesurés et enregistrés à quatre moments: (1) Après l'installation des canules dans la chambre de pré-induction alors que le malade respirait l'air de la pièce. (2) Après le transfert du patient en salle d'opération et sous ventilation spontanée à 100 pour cent d'oxygène. (3) Une à deux minutes après l'injection de maléate de midazolam à la dose de $0.2 \mathrm{mg} \cdot \mathrm{kg}^{-1}$. (4) Quatre à cinq minutes après cette mème injection. L'index cardiaque, l'index d'éjection, le produit fréquence cardiaque-pression systolique, les index de résistance vasculaire systémique et pulmonaire. les index de travail d'éjection ventriculaire gauche el droit ont également été calculés aux mêmes temps.

Le midazolam a produit l'hypnose chez tous les patients entre 30 et 90 secondes (moyenne de 44 secondes).

Une apnée de 15 à 60 secondes a été observée dans 75 pour cent des cas alors que la ventilation a èté assistée.

La $\mathrm{Pa}_{\mathbf{O}_{2}}$ est demeurée inchangée après l'injec-

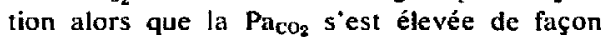
significative $(\mathrm{p}<0.02)$ passant de $5.32 \pm 0.19$ à $5.85 \pm 0.17 \mathrm{kPa}(46 \pm 1.3 \mathrm{~mm} \mathrm{Hg})$ quatre à cinq minutes après le midazolam.

Les effets hémodynamiques observés ont étê mineurs et moins importants dans la plupart des cas que ceux associés au transfert des patients en salle d'opération alors que les pressions artériel. les systolique, diastolique et moyenne, que la pression capillaire bloquée et que l'index de résistance vasculaire systémique se sont tous élevés de façon significative $(p<0.01)$. Le midazolam a diminué significativement les pressions artérielles systémiques (systolique, diastolique et moyenne). le volume d’éjection. Ies index de travail ventriculaire gauche et droil ainsi que l'index de résistance vasculaire périphérique, tout cela vers des valeurs voisines des valeurs-contrôles.

La fréquence cardiaque s'est éle vée de $55 \pm 6.6$ à $66 \pm 5.3$ par minute, une à deux minutes après l'injection de la benzodiazépine alors que les pressions artérielles moyennes systémiques et pulmonaires, les pressions pulmonaires bloquées, les index cardiaques, l'index d'éjection et celui de la résistance vasculaire pulmonaire ainsi que le produit pression-fréquence demeuraient inchangés. L'on n'a pas observé d'autres modifications significatives quatre ou cinq minutes après l'injection si ce n'est le maintien du déclin des pressions systémiques systoliques et diastoliques vers les niveaux-contrôles (125/61).

Nous concluons que la rapidité d'action du maléate de midazolam et ses effets hémodynamiques légers en font un agent d'induction sûr et efficace chez les coronariens.

\section{REFERENCES}

1. Reves J G Corssen G \& Holcomb C Comparison of two benzodiazepines for anaesthesia induction: midazolam and diazepam. Canad. Anaesih. Soc. J. 25: $211-214$ (1978).

2. Reves, J G Vinik, R, Hirschfield A. M. Hoi come. C.M. \& Strong.S. Midazolam compared with thiopental as a hypnotic component in balanced anesthesia: a randomized. double-blind study. Canad. Anaesth. Soc. J. 26: 42-49 (1979)

3. Conner, J.T. Katz. R.L., Pagano, R.R. Graham. C.W. Ro 21.3981 for intrivenous surgical premedication and induction of anesthesia. Anesth. Analg. 57: 1-5 (1978).

4. Fragen, R.J. Gahl, F \& Caldwell. N A water-soluble benzodiazepine, Ro 21-3981, for induction of anesthesia. Anesthesiology 49: 41-43 (1978).

5. Puglisi. C.V.. Meyer. J.C.. D'ArConte. L.. BrooK 5. M.A. \& DE SILVA. J.A.F. Determination of water-soluble-1. -4-benzodiazepines in blood by electron-capture gas liquid chromatography and in urine by differential puise polarography. J. Chromatogr. 145: 81-96 (1978).

6. Brown, C.R., Sarnquist. F.H. \& Pedley. T.A. Ro 21-3981: Clinical. electroencephalographic and 
pharmacokinetic study (Abstr). American Society of Anesthesiologists Annual Meeting, 1977. p 421

7. Brown, C.R., Sarnouist, F.H., Mathers. W.D. Brock-Utne. J.G.. Canup. C.A. \& Carr B.L.: Clinical comparison of midazolam maleate with thiopental as anaesthelic induction agents. (Abstr) American Society of Anesthesiologists Annual Meeting. 1978, pp 13-14.

8. Reves. J.G. Mardis. M. \& Strong. S. Cardiopulmonary effects of midazolam. Alabama $J$. Med. Sci. 15: 347-351 (1978).

9. Jones. D.J., Stehling. L.G. \& Zauder. H.L. The effects of Ro 21-3981, a new water soluble benzodiazepine, on the cardiovascular system in dogs (Abstr.) American Society of Anesthesiologists Annual Meeting. 1977, pp. 525-526.

10. Gooding. J.M.. Dimick. A.R. TAVakoli. M. \& CURSSEN. G. A physiologic analysis of cardiopulmonary responses to ketamine anesthesia in noncardiac patients. Anesth. Analg. 56:813(1977).

11. Khatri. I.M. \& Freis, E.D. Hemodynamic changes during sleep. J. Appl. Phy siol. 22: 867-873 (1967).

12. Cote. P., Gueret. P. \& Bourassa, M.G. Systemic and coronary hemodynamic effects of diazepam in patients with normal and diseased coronary arteries. Circulation 50: 1210-1216 (1974).

13. Cote. P., Campeau, L. \& Bourassa, M.g. Therapeutic implications of diazepam in patients with elevated left ventricular filling pressure. Am. Heart J. 91: 747-75I (1976).

14. Jackson, A.P.F. Dhadphale, P.R., CalLAGHAN. M.L. \& ALSERI, S. Haemodynamic studies during induction of anaesthesia for openheart surgery using diazepam and ketamine. Br. J. Annesth. 50: 375-378 (1978).

15. Prakash, R., Thurer, R., Varoas, A. \& Diaz.
P.D. Cardiovascular effects of diazepam surgery (Abstr.). American Society of Anesthesiologists Annual Meeting, 1976. pp 263-269.

16. Samuelson. P.N., Lell. W.A. \& Kouchoukos. N.T. Study of hemodynamics during anaesthetic induction in patients for coronary artery bypass grafting (Abstr.) V European Congress of Anaesthesiology. Exerpta Medica 452: 277-278 (1978).

17. Cullen. D.J., Eger, E.I. \& Gregory. G.A. The cardiovascular effects of carbon dioxide in man. conscious and during cyclopropane anesthesia. Anesthesiology 3/: 407-4I3 (1969).

18. Catchlove, R.F.H. \& Kafer. E.R. The effects of diazepam on the ventilatory response to carbon dioxide and on steady-state gas exchange. Anesthesiology 34: 9-13(1971).

19. Reves, J.G.. Lell. W.A.. McCracken. L.E. Kravetz. R.A. \& Prough. D.S. Comparison of morphine and ketamine anesthetic techniques for coronary surgery: a randomized study. South Med. J. 71: 33-37 (1978).

20. Lell. W.A., Walker. D.R., Blackstone, E.H.. Kouchoukos, N.T., Al.larde, R. \& RoE. C.R. Evaluation of myocardial damage in patients undergoing coronary-artery bypass procedures with halothane- $\mathrm{N}_{2} \mathrm{O}$ anesthesia and adjuvants. Anesth. Analg. 56: 556-563 (1977).

21. Reves. J.G.. SAmuelson. P.N., Lell. W.A., Allakde. R.R., YOUnES, H.M. \& OGLT, S. Anesthesia for coronary artery surgery: an evolition in anesthetic management. Ala. J. Med. Sci. 14: 394-400 (1977).

22. Gorel. F.L., Norostrom. L.A.. Nelson, R.R., Jorgensen. C.R. \& Wang Yang. The rate. pressure product as an index of myocardial oxygen consumption during exercise in patients with angina pectoris. Circulation $57: 549-556$ (1978). 